\title{
FAKTOR RISIKO KEJADIAN ISPA DI DESA SUGIHWARAS KECAMATAN MAOSPATI KABUPATEN MAGETAN JAWA TIMUR TAHUN 2016
}

Feny Hardianingtias, Mujiyono, Hery Koesmantoro

\begin{abstract}
Almost $90 \%$ of people in Sugihwaras Maospati District have a business of making brick. The burning process was done in their own yard and lead to air population. The purpose of this research is to identify indoor and outdoor physical factor of Acute Respiratory Infections in that village. Measurement of the physical condition of the houses such as ligthing, temperature, and humidity were done. This research is a descriptive study. The data collection is done by observation, interview, and measurement of the physical condition of the house. The samples of this research are 94 houses taken by proportional random sampling. Then, data were analyzed using distribution tables.

The research concluded that Acute Respiratory Infections were influenced by some indoor's factors, ligthing was $58,51 \%$ and by outdoor's factor was $73,4 \%$, there was still smoke that could be harmful for the people.

So the sugestion for villagers who have a business of making brick have to wear mask in the manufacturing process, especially during the burning process.
\end{abstract}

\section{PENDAHULUAN}

\section{Dewasa}

menyebabkan 4,25 juta kemat dunia setiap tahun. ISPA juga merupakan penyebab utama penyakit pada anak-anak dan pembunuh utama.20-40\% dari semua rawat inap antara anak-anak adalah karena infeksi saluran pernapasan akut. Pneumonia menyebabkan hampir 1,6 2 juta kematian per tahun pada anak balita dan menjadi pembunuh global terbesar dalam kelompok umur balita (WHO, 2012).

Indonesia merupakan negara dengan iklim tropis sehingga berpotensi menjadi daerah yang endemik dari beberapa penyakit infeksi yang setiap saat dapat menjadi ancaman bagi kesehatan masyarakat. Pengaruh geografis dapat mendorong terjadinya peningkatan kasus maupun kematian penderita akibat ISPA, misalnya pencemaran lingkungan yang disebabkan oleh asap karena kebakaran hutan, gas buangan yang berasal dari sarana transportasi dan polusi udara dalam rumah karena asap dapur, asap rokok, perubahan iklim global antara lain perubahan suhu udara, kelembaban dan curah hujan yang merupakan ancaman kesehatan terutama pada penyakit ISPA.

Pada tahun 2011, seluruh kabupaten/kota telah melaksanakan program pengendalian ISPA. Di mana penemuan dan tatalaksana kasus ISPA Balita di Jawa Timur tahun 2011 sebanyak 75.721 balita $(25,24 \%$ dari 300.029 perkiraan kasus ISPA yang harus ditemukan). Kabupaten Gresik menduduki peringkat pertama pencapaian cakupan ISPA Balita sebesar 100,22\%.

Di Kabupaten Magetan, kejadian penyakit ISPA sudah sangat tinggi. Menurut data dari Dinas Kesehatan Kabupaten Magetan penyakit ISPA merupakan penyebab utama dari angka kematian. Data Dinas Kesehatan Kabupaten Magetan mencatat, sejak memasuki musim kemarau pada bulan Juli tahun 2011 lalu, jumlah penderita penyakit ISPA yang disertai dengan pneumonia mencapai 56 orang sedangkan penyakit ISPA nonpneumoniamencapai 2.011 orang (Louis, 2011).

Kabupaten Magetan memiliki 22 puskesmas yang tersebar di 18 Kecamatan, salah satu Puskesmas yang menjadi rujukan penderita penyakit ISPA adalah Puskesmas Maospati. Berdasarkan data yang diperoleh dari Puskesmas Maospati diketahui salah satu desanya, yaitu Desa Sugihwaras Kecamatan Maospati memiliki angka kejadian penyakit ISPA sebesar 102 kasus dalam 3 tahun terakhir.

Di Desa Sugihwaras Kecamatan Maospati merupakan desa dengan hampir $90 \%$ masyarakat memiliki usaha pembuatan batu bata yang proses pembakarannya dilakukan di halaman depan rumah. Hal ini dapat menyebabkan, asap yang ditimbulkan dari pembakaran batu bata terhirup oleh masyarakat sekitar yang berada di dekat rumah tersebut. Apabila, asap tersebut terhirup dan masuk ke dalam saluran pernapasan dapat menyebabkan timbulnya penyakit ISPA. Selain itu, lingkungan di sekitar rumah yang melakukan pembakaran 
akan tercemar dan udara di sekitar menjadi tidak sehat lagi.

Berdasarkan dari latar belakang di atas dan teori yang ada, maka peneliti tertarik melaksanakan penelitian di Desa Sugihwaras Kecamatan Maospati Kabupaten Jawa Timur mengenai kejadian penyakit ISPA dengan kondisi fisik rumah.

Penelitian ini bertujuan untuk Mengetahui faktor fisik di dalam dan di luar rumah sebagai penyebab timbulnya penyakit ISPA di Desa Sugihwaras Kecamatan Maospati Kabupaten Magetan Jawa Timur.

\section{METODE PENELITIAN}

Jenis penelitian ini menggunakan metode penelitian deskriptif.Penelitian deskriptif adalah salah suatu metode penelitian yang dilakukan dengan tujuan utama dengan membuat gambaran atau deskriptif tentang suatu keadaan secara objektif (Notoatmodjo, 2005).

Berdasarkan dengan metode di atas peneliti akan menggambarkan keadaan yang diperoleh dari hasil wawancara (melalui kuesioner), observasi dan pengukuran parameter yaitu pencahayaan, suhu dan kelembaban di Desa Sugihwaras Kecamatan Maospati Kabupaten Magetan Jawa Timur.

Lokasi penenlitian dilakukan pada rumah penduduk di Desa Sugihwaras Kecamatan

HASIL DAN PEMBAHASAN

Hasil Pengukuran Pencahayaan
Maospati Kabupaten Maospati Jawa Timur.Peneliti mengambil penelitian di lokasi tersebut karena Desa Sugihwaras Kecamatan Maospati Kabupaten Maospati Jawa Timur merupakan desa yang sebagian besar penduduknya memiliki usaha batubata.

Populasi dalam penelitian ini adalah seluruh penduduk Desa Sugihwaras Kecamatan Maospati Kabupaten Magetan Jawa Timur sejumlah 5.052 jiwa dan 1.446 rumah.

Teknik pengambilan sampel ini menggunakan Proporsional random sampling dikatakan simpel atau sederhana dikarenakan dalam pengambilan sampel dari populasi itu memang dilakukan secara acak tanpa harus memperhatikan strata.Dari besar sampel 94 rumah dibagi menurut per RW dengan pertimbangan yang dipilih yaitu rumah dengan memiliki usaha pembuatan batu bata.

Dalam pengolahan data yaitu menggunakan data yang diperoleh dari hasil pengukuran dan observasi disajikan dalam bentuk data untuk memudahkan menganalisa data.

Dalam penelitian ini menggunakan analisis deskriptif yaitu data yang telah terkumpul dari hasil pengukuran dan observasi dianalisa secara deskriptif dengan menggunakan analisa tabel.

Tabel 1

Hasil Pengukuran Fisik Pencahayaan Rumah Responden Desa Sugihwaras Tahun 2016

\begin{tabular}{cccc}
\hline No. & Pencahayaan & Jumlah Rumah & Prosentase (\%) \\
\hline 1. & Tidak Memenuhi Syarat & 55 & 58,51 \\
\hline 2. & Memenuhi Syarat & 39 & 41,49 \\
\hline & Jumlah & 94 & 100 \\
\hline
\end{tabular}

Berdasarkan Tabel 1 Hasil Pengukuran Fisik Pencahayaan Rumah Responden Desa Sugihwaras Tahun 2016 didapatkan hasil bahwa dari 94 rumah yang tidak memenuhi syarat sebanyak 55 rumah $(58,51 \%)$, sedangkan 39 $(41,49 \%)$ rumah sudah memenuhi syarat. Rata rata hasil pengukuran pencahayaan di rumah responden yang tidak memenuhi syarat adalah 35 lux, sedangkan persyaratan yang memenuhi adalah 80 lux.

\section{Denganadanya}

pencahayaan yang merata di dalam rumah diharapkan dapat mencegah berkembangbiaknya virus atau bakteri penyebab penyakit ISPA. Dengan pencahayaan yang tidak memenuhi syarat tersebut dipastikan bahwa di dalam rumah khususnya pada bagian kamar yang dilakukan pengukuran sebagai tempat perkembangbiakkan virus atau bakteri penyakit salah satunya adalah penyakit ISPA (Kusnoputranto, 2000).

Pencahayaan yang terdapat di 55 rumah dari 94 rumah yang tidak memenuhi syarat adalah gelap pada siang hari.Cahaya yang gelap pada siang hari ini, dikarenakan kurang berfungsinya ventilasi di dalam rumah masing masing rumah dari rumah responden.Kondisi seperti inilah yang dapat menyebabkan pencahayaan di dalam rumah tidak memenuhi syarat. 
Hasil Pengukuran Suhu

Tabel 2

Hasil Pengukuran Fisik Suhu Rumah Responden di Desa Sugihwaras Tahun 2016

\begin{tabular}{cccc}
\hline No. & Suhu & Jumlah Rumah & Prosentase (\%) \\
\hline 1. & Tidak Memenuhi Syarat & 5 & 5,31 \\
\hline 2. & Memenuhi Syarat & 89 & 94,69 \\
\hline & Jumlah & 94 & 100 \\
\hline
\end{tabular}

Berdasarkan Tabel 2 Hasil Pengukuran Fisik Suhu Rumah Responden Desa Sugihwaras Tahun 2016 didapatkan hasil bahwa dari 94 rumah yang tidak memenuhi syarat sebanyak 5 rumah $(5,31 \%)$, sedangkan $89(94,69 \%)$ rumah sudah memenuhi

syarat. Menurut Kepmenkes RI No. 829/Menkes/SK/VII/1999, syarat untuk pengukuran suhu adalah $18^{\circ} \mathrm{C}-30^{\circ} \mathrm{C}$.

Dengan adanya suhu yang nyaman dan memenuhi syarat dapat membantu kelangsungan

\section{Hasil Pengukuran Kelembaban}

Tabel 3

Hasil Pengukuran Fisik Kelembaban Rumah Responden Desa Sugihwaras Tahun 2016

\begin{tabular}{cccc}
\hline No. & Kelembaban & Jlh rmh & Prosentase (\%) \\
\hline 1. & Tidak Memenuhi Syarat & 15 & 15,95 \\
\hline 2. & Memenuhi Syarat & 79 & 84,05 \\
\hline & Jumlah & 94 & 100
\end{tabular}

Berdasarkan Tabel 3 Hasil Pengukuran Fisik Kelembaban Rumah Responden Desa Sugihwaras Tahun 2016 didapatkan hasil bahwa dari 94 rumah yang tidak memenuhi syarat sebanyak 15 rumah $(15,95 \%)$, sedangkan 79 $(84,05 \%)$ rumah sudah memenuhi syarat. Menurut Kepmenkes RI No. 829/Menkes/SK/VII/1999, syarat untuk kelembaban adalah $50 \%-70 \%$.

Kelembaban yang ada di dalam rumah juga sangat berpengaruh dalam perkembangbiakkan virus atau bakteri suatu penyakit.Dengan kelembaban yang baik dan memenuhi syarat dapat hidup penghuni yang ada di dalam rumah (Kusnoputranto, 2000).Sedangkan, apabila suhu yang berada di dalam rumah tidak memenuhi syarat, dapat menghambat kelangsungan hidup penghuni di dalam rumah. Hal ini dikarenakan, suhu yang berada di dalam rumah akan mempengaruhi berkembangbiaknya virus dan bakteri penyebab penyakit. Dengan suhu yang tidak memenuhi syarat, virus dan bakteri penyebab penyakit seperti penyakit ISPA yang berkembangbiak pada suhu $>20$ akan tumbuh dan berkembangbiak semakin banyak. memperlambat perkembangbiakkan virus atau bakteri penyebab penyakit (Kusnoputranto, 2000).

Kelembaban dan suhu merupakan dua faktor yang saling berhubungan erat dengan perkembangan virus atau bakteri penyakit.Semakin tinggi kelembaban semakin rendah suhu yang ada di dalam rumah, sehingga dapat mempercepat perkembangbiakan virus atau bakteri penyebab penyakit.Dan sebaliknya, semakin rendah kelembaban yang ada di dalam rumah semakin tinggi pula suhu yang di dalam rumah, sehingga dapat memperlambat perkembangbiakkan virus atau bakteri suatu penyakit.

Hasil Observasi Jenis Penggunaan Bahan Bakar

Tabel 4

Distribusi Penggunaan Bahan Bakar Memasak di Desa Sugihwaras Tahun 2016

\begin{tabular}{cccc}
\hline No. & Kriteria & Jumlah & $\begin{array}{c}\text { Prosentase } \\
(\%)\end{array}$ \\
\hline 1. & LPG & 81 & 86,17 \\
\hline 2. & Kayu Bakar & 13 & 13,83 \\
\hline & Jumlah & 94 & 100 \\
\hline
\end{tabular}


Berdasarkan Tabel Distribusi Penggunaan Bahan Bakar Memasak Desa Sugihwaras Tahun 2016 didapatkan hasil bahwa 13 rumah responden dari 94 rumah responden masih menggunakan kayu bakar (13,83\%). Sedangkan, 81 rumah responden dari 94 rumah responden sudah menggunakan LPG $(86,17 \%)$.
Jenis penggunaan bahan bakar dalam memasak sangat berpengaruh dalam mempercepat timbulnya penyakit gangguan pernapasan seperti penyakit ISPA. Pemilihan bahan bakar yang baik akan sangat berpengaruh dalam timbulnya penyakit gangguan pernapasan.

\section{Hasil Observasi Kepadatan Hunian}

Tabel 5

Distribusi Kepadatan Hunian di Desa Sugihwaras Tahun 2016

\begin{tabular}{cccc}
\hline No & Kriteria & Jumlah & $\begin{array}{c}\text { Prosentase } \\
(\%)\end{array}$ \\
\hline 1. & Tidak Memenuhi Syarat & 71 & 75,54 \\
\hline 2. & Memenuhi Syarat & 23 & 24,46 \\
\hline & Jumlah & 94 & 100 \\
\hline
\end{tabular}

Berdasarkan Tabel 5, Distribusi Kepadatan Hunian di Desa Sugihwaras Tahun 2016 didapatkan hasil bahwa 71 rumah responden dari 94 rumah responden memiliki kepadatan hunian yang padat dengan prosentase 75,54\%. Sedangkan, 23 rumah responden dari 94 rumah responden memiliki kepadatan hunian yang tidak padat dengan prosentase $24,46 \%$.

Kepadatan hunian di dalam rumah merupakan banyaknya orang yang tinggal atau berada di dalam rumah dengan ukuran luas rumah. Menurut Kepmenkes No. 829/Menkes/SK/VII/1999, luas kamar tidur minimal $8 \mathrm{~m}^{2}$ dan dianjurkan tidak untuk lebih dari 2 orang (Ade Irawan. 2012).

\section{Hasil Observasi Pembakaran Di Luar Rumah}

Tabel 6

Hasil Observasi Asap Pembakaran Di Luar Rumah Responden Desa Sugihwaras Tahun 2016

\begin{tabular}{cccc}
\hline No. & Kriteria & Jumlah & Prosentase $(\%)$ \\
\hline 1. & Ada & 69 & 73,4 \\
\hline 2. & Tidak Ada & 25 & 26,6 \\
\hline & Jumlah & 94 & 100 \\
\hline
\end{tabular}

Berdasarkan Tabel 6 Hasil Observasi Asap Pembakaran Di Luar Rumah Responden Desa Sugihwaras Tahun 2016 didapatkan hasil bahwa 69 rumah dari 94 rumah memiliki asap pembakaran di luar rumah (26,6\%). Sedangkan, 25 rumah dari 94 rumah tidak memiliki asap pembakaran di luar rumah $(73,4 \%)$.

\section{Hasil Observasi kejadian Penyakit ISPA}

Kejadian Penyakit ISPADesa Sugihwaras Tahun 2016

\begin{tabular}{cccc}
\hline No. & Kriteria & Jumlah & Prosentase (\%) \\
\hline 1. & Sakit & 55 & 58,50 \\
\hline 2. & Tidak Sakit & 39 & 41,5 \\
\hline & Jumlah & 94 & 100 \\
\hline
\end{tabular}

Dengan adanya asap pembakaran yang selalu terhirup oleh penghuni atau masyarakat di sekitar rumah akan mempercepat terkena penyakit saluran pernapasan terlebih apabila pengusaha tersebut tidak menggunakan APD dalam proses pembuatan batu bata. Dengan menggunakan APD yang baik dan benar akan memperlambat terkena penyakit ISPA. 
Berdasarkan Tabel 7 Kejadian Penyakit ISPA Desa Sugihwaras Tahun 2016 didapatkan hasil bahwa 55 rumah dari 94 rumah terdapat penderita penyakit ISPA pada waktu penelitian (58,50\%). Sedangkan, 39 rumah dari 94 rumah tidak terdapat penderitapenyakit ISPA pada waktu penelitian $(41,5 \%)$.

Kejadian penyakit ISPA ini dikarenakan, sebagian besar responden merasakan gejala

\section{KESIMPULAN DAN SARAN}

Faktor kondisi fisik di dalam rumah sangat berpengaruh terhadap kejadian penyakit ISPA di Desa Sugihwaras Kecamatan Maospati Kabupaten Magetan. Pencahayaan di dalam rumah merupakan faktor risiko yang sangat berpengaruh terhadap kejadian penyakit ISPA yaitu sebesar $58,51 \%$. Adanya asap pembakaran dari proses pembuatan batu bata yang ada di Desa Sugihwaras yaitu sebesar $73,4 \%$.

Dari kesimpulan di atas, sebaiknya rumah responden memiliki ventilasi yang berfungsi

\section{DAFTAR PUSTAKA}

Achmadi, U.F. 1991. Faktor - faktor Penyebab ISPA Dalam Rumah Tangga Di Jakarta Tahun 1990 -1991.Jakarta : Lembaga Penelitian Universitas Indonesia

Ade Irawan. 2012. Hubungan Lingkungan Fisik Rumah Dengan Kejadian Infeksi Saluran Pernafasan Akut Pada Anak Balita di Kabupaten Wonosobo Provinsi Jawa Tengah Tahun 2012.Depok : Universitas Indonesia

Anonymous.2013. Hasil Riset Dasar Kesehatan Nasional. Jakarta : Dinkes

www.Depkes.go.id/resources/download L.../Hasil\%20Riskesdas\%202013. _pdf diakses tanggal 19 Januari 2016

BPOM.2000. Informatorium Obat Nasional Indonesia.Jakarta : Badan Pengawas Obat dan Makanan Republik Indonesia

Kurniawan. 2009. Infeksi Saluran Pernapasan Akut (ISPA) dan Tanda Tanda Bahaya ISPA in www.pps.unud.ac.id/thesis/pdf.../unud1529-1503206930-bab\%20ii.pdf diakses tanggal 19 Januari 2016

Louis Rika. 2011. Jumlah Penderita Diare dan ISPA di Magetan Tinggi. Magetan in www.antarjatim.com/lihat/berita/71749/juml ah-penderita-diare-dan-ISPA-di-Magetantinggidiakses tanggal 19 Januari 2016

Muchlisin. 2013. Infeksi Saluran Pernafasan Akut. Jakarta in www.kajianpustaka.com/2013/07/infeksisaluran-pernafasan-akut-ispa.html diakses tanggal 21 Januari 2016 awal penyakit ISPA yaitu dari udara atau cuaca yang tidak menentu, selain itu terdapatnya asap pembakaran dari proses pembuatan batu bata yang tidak diimbangi dengan cuaca yang baik. Sehingga, pada saat melakukan penelitian jumlah kejadian penyakit ISPA cukup banyak terjadi.

dengan baik sebagai tempat pertukaran udara dan pencahayaan yang terdapat di dalam rumah bisa memenuhi syarat.Rumah dengan pencahayaan yang kurang sebaiknya melakukan pemasangan genteng kaca di masing - masing bagian rumah yang terlihat gelap dan penambahan ventilasi di setiap bagian rumah. Sebaiknya, dalam melakukan proses pembuatan batu bata menggunakan APD seperti masker untuk mencegah terjadinya penyakit ISPA.

Notoatmodjo, Soekidjo. 2007. Kesehatan Masyarakat IImu dan Seni.Jakarta : Rineka Cipta

Rasmaliah. 2004. Infeksi Saluran Pernapasan Akut (ISPA) dan Tanda Tanda Bahaya ISPA in www.pps.unud.ac.id/thesis/pdf.../unud1529-1503206930-bab\%20ii.pdf diakses tanggal 19 Januari 2016

Rasmaliah. 2008. Infeksi Saluran Pernafasan Akut (ISPA) dan Penanggulangannya in http://libryary.usu.ac.id diakses tanggal 21 Januari 2016

Sariana. 2005. Penyakit ISPA. Jakarta : Depkes RI

http://www.academia.edu/5113721/ISP A diakses tanggal 21 Januari 2016

Slamet. 2007. Syarat Kuantitatif Air. Jakarta in repository.usu.ac.id/bitstream/123456789/2 7601/4/Chapter\%20II.pdf diakses pada tanggal 21 Januari 2016

Wardhana.2004. Penyediaan Air Bersih. Jakarta in

repository.usu.ac.id/bitstream/123456789/2 7601/4/Chapter\%20II.pdf diakses pada tanggal 21 Januari 2016

WHO. 2011. Global Status Report on Noncommunicable Diseases 2011 inhttp://www.who.int/nmh/publications/ncd report chapter1.pdf diakses tanggal 21 Januari 